\title{
Evaluating the Project HOPE's Enhancing Reading Skills Activity: Basis for Community Literacy Program to Persons Deprived of Liberty
}

\author{
Abel V. Alvarez, Jr. and Laira Janelle C. Contreras \\ Far Eastern University, \\ Manila, Philippines
}

\begin{abstract}
Project HOPE or Harnessing Offenders' Personal Empowerment is one the flagship programs of Far Eastern University- Community Extension Services. It caters incarcerated female individuals in Manila City Jail, Sta. Cruz, Manila which reflects the university's response towards inclusiveness in providing community development programs. Through this, the FEUInstitute of Education introduced enhancing reading skills program to 10 selected Persons Deprived of Liberty (PDL) in Manila City JailFemale Dormitory, Sta. Cruz, Manila. This is in response to the study conducted by [19] where educational needs are one of the primary programs that PDL's need. A purposive sampling method was used for the selection of 10 participants. A postevaluative program questionnaire was given to respondents to evaluate the program, and collected data were analyzed using descriptive research method. Meanwhile, teacher volunteers were asked to share their experiences during their immersion services to Manila City Jail-Female Dormitory, Sta. Cruz, Manila. Descriptions of their reflexivity paper were analyzed using thematic analysis. Findings revealed that community literacy program like this are beneficial to $P D L$ residents as it addresses their educational needs and supports knowledge growth. This paper discusses the impact of enhancing reading skills program of FEU-IE to PDL participants in Manila City Jail-Female Dormitory as it highlights experiences of teacher volunteers in the immersion. Results of this study serves for comprehensive and tailor-fit enhancing reading skills program to future PDL participants.
\end{abstract}

\section{Introduction}

A number of scholars considered the physiognomies of many county jails in general [10], [21], [26], [28]. The relevant findings propose shared situations met by small jail administrators across the world. Jail populations and their needs are diverse, but jail and community service is low: "there is little uniformity across jails," making it difficult to offer comparisons, but they generally have "no or very little community-based system to facilitate the transition process" [24].
In the same manner, when individuals leave jails, they reenter the community without having had the same opportunity for educational programs that they would have had if they were confined in a prison. At the county level, little is known about community reentry. With this in mind, Far Eastern University's (FEU) Project HOPE or Harnessing Offenders' Personal Empowerment, as identified in its active role in the society to promote hopefulness and positivity, foresees that Persons Deprived of Liberty (PDL) can reenter the community after their life in jail with confidence, renewed perspectives, and set of values derived from the reading literacy programs they have earned and experienced through educators and students who volunteer to immerse and teach inside the prison.

To gradually address the problem, the trifocalization function of higher education institution (HEI) which involves instruction, research, and extension, gave birth to community development programs in the Philippines. Colleges and universities in the country are not confined to teaching and research role but they also see the responsibility to nurture and to give back to the marginalized members of our society. Primarily, they provide extension services through sharing their program expertise outside the four corners of classroom. HEIs, therefore, hold the duty of bringing physical teaching and learning environment to the community.

Since 1990's, FEU, through Community Extension Services (CES), has maintained its pledge to provide inclusive services to PDL at Manila City Jail, Sta. Cruz, Manila. From its original concept of dole-out or outreach program in the areas of health, physical development, legal and psycho-social services, education, and economic well-being, FEU widens and reinforces its vision by introducing longterm and sustainable community development and research-based programs.

Project HOPE is one of the flagship community extension programs of FEU that aims to holistically transform the lives, alleviate the plight, and improve socio-economic status of PDLs [19] by coming up with different research-based programs that are aligned to the needs of the community. The university believes that every individual has intrinsic goodness that is necessary in providing various community development programs towards assistance to move forward and to transform as an active and responsible Filipino citizen. Project HOPE echoes the notion of being a man for others which is the university's 
response towards being an institution who gives priority and importance to social responsibility.

In line with the previous presupposition, studies reveal that there is a general agreement that prisoners can improve themselves through education [16], [22], [25], [27]. It was also emphasize that the history of correctional education can be traced back 200 years to the time when ministers volunteered to teach reading in the prisons in order that inmates would be able to read the Bible; in more modern times, correctional education is linked to lower recidivism rates [16].

In the university's aspiration 2020, one of the key program areas of CES is geared towards people empowerment which covers literacy or educational programs for the totality of individual's development. The campaign against illegal use of drugs of the current Philippine President, Rodrigo Roa Duterte resulted in the rapid increase of being detained, making the country jails congested, with the basic needs of PDLs being compromised. According to [19], 80.60\% of the respondents in Manila City JailFemale Dormitory, Sta. Cruz, Manila were imprisoned due to the violation of RA 9165 of 2002 or Dangerous Drugs Act. Statistical report revealed that $26.93 \%$ of the barangays in the country are drugaffected due to illegal use of drugs [20].

Results of the community needs assessment study revealed that aside from livelihood, health, and psychological programs, one of the needs of PDLs include literacy or educational programs [19]. In fact, results show that out of 94 respondents using a descriptive survey, $36.20 \%$ had not able to finish high school. This was supported by [3] where they emphasize that $40 \%$ had reached high school, but not necessarily finished secondary education. Thus, underemployment and unemployment are two of the main products of lack of education among PDLs [4].

Further studies also revealed that poverty incidence is correlated with educational attainment of one's individual wherein "almost $30 \%$ of those who did not complete high school are poor... and around $67 \%$ of the poor household heads were elementary school graduates or lower" [2]. [15] also explained the concept of "trapped in a cycle of poverty" (e.g., Phillips and Harm, 1998) wherein educational attainment can likewise be a contributing factor for being in blue collar job. This was revealed in the study conducted in Manila City Jail-Female Dormitory by [19]. Likewise, high unemployment incidence of most incarcerated women [3] can also be associated to the degree of educational attainment by individuals.

Along with livelihood programs, psychological services, and health activities, literacy programs addressed the needs of the PDLs in Manila City JailFemale Dormitory. As such, FEU-Institute of Education (IE) took the lead in spearheading and extending their expertise in the area of educational programs. The institute's mission highlights “...promotes quality outcomes-based, values-laden, progressive, collaborative, innovative, and researchbased teacher education and training for practitioners in the local, national, and international educational systems, nurturing service-oriented, competent and morally upright citizens" [9]. In addition, FEU-IE pointed out the spirit of volunteerism, community, and entrepreneurship as one of their goals to instill with their faculty and students.

With its longstanding achievement in the education sector and being considered as a top caliber having been conferred by Commission on Higher Education as Center of Excellence, the FEU-IE pool of faculty, employee, and student volunteers introduced enhancement reading skills program to selected PDL residents in Manila City Jail-Female Dormitory.

The findings of this paper are noteworthy to both the institution and the partner community for it will pave the way for more comprehensive and tailor-fit reading skills program to PDLs, considering the diversity of the PDL learners in Manila City JailFemale Dormitory. In addition, faculty, employee, and undergraduate and graduate student community extension volunteers will have concrete basis for developing and designing reading teaching materials and instructional andragogic approaches suited for adult learners.

\section{Statement of the problem}

This paper aims to determine the impact of enhancing reading skills program of FEU-IE to 10 selected PDL participants in Manila City Jail-Female Dormitory. Specifically, the research is intended to answer the following questions:

2.1. What are the insights and responses of PDLs regarding the enhancing reading skills program of FEU's Project HOPE?

2.2. What actual teacher experiences transpired during the immersion teachings at Manila City Jail-Female Dormitory?

\section{Conceptual Framework}

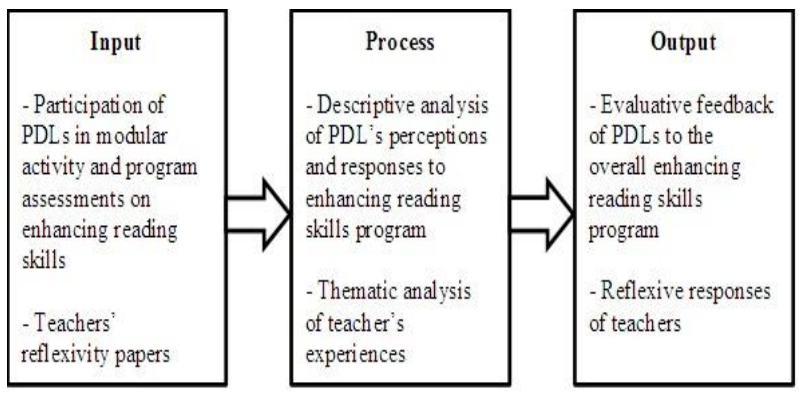

Figure 1: Research paradigm showing the relationship between the inputs, its processes, and the projected output of the study 


\section{Methods}

Participants of the enhancing reading skills program were from Manila City Jail-Female Dormitory, Sta. Cruz, Manila. The activity was conducted in four sessions. Each session was facilitated by faculty and student volunteers from FEU-Institute of Education. This scholarly pursuit employed purposive sampling to select 10 participants. The inclusion criteria include: elementary graduates or high school undergraduates; willingness to participate in the program; and committed to finish the modular sessions.

The studied features of efficacious literacy programs in prisons and established four qualities [27]. Primarily, programs should be learner centered by addressing the exceptional, individual needs of inmates. Programs should recognize the copious learning styles of participants, attempt to address the wide range of literacy skills, and respect the cultural diversity of participants. Secondly, programs should employ instructional materials that are used in meaningful contexts and sustain the needs of the participants. Third, instruction should be engaging and motivating to sustain attention. The textbooks and materials should be significant, and if possible, the participants own writing should be incorporated into the lessons. Fourth, participants should see themselves in a role other than that of "prisoner" or "inmate." This means they should be treated with the same respect as human beings who function in society outside their constraints [23].

Following the literature, a teacher volunteer, on his Critical Thinking Session with the inmates, used the story, Ang Kuneho at ang Pagong as content. It was posited that this Philippine children's story encourages learners to reflect on what is read, exercise decision making, and make judgment and valuing, as posited by [18], in their study on Trends in Reading Instruction.

Socratic Questioning, a philosophical method of systematic doubt and questioning, was employed by the volunteer teacher as a preliminary technique to elicit understanding and sentiments about the story. Afterwards, Question Circle was employed to provide a logical, yet flexible, format for questioning. It is composed of three circles: matter, personal reality and external reality. The latter activity, then, provided opportunities for the inmates to create questions in groups regarding the realizations they have drawn out from the story.

Instructional scaffolds, such as those mentioned above, promote learning through dialogue, feedback, and shared responsibility. Through the supportive and challenging learning experiences gained from carefully planned scaffolded learning, instructors can help students become lifelong, independent learners [1]. A post-evaluative questionnaire, translated from English to Filipino, was utilized to 10 PDL after the immersion teaching. Likewise, volunteers assisted the respondents in answering the instrument. The descriptive research method was employed to analyze the collected data.

Meanwhile, reflexivity papers were collected from five teacher volunteers who served as facilitators during the implementation of enhancing reading skills program. They were selected by the institute based from their time availability and expertise. Teacher volunteers shared experiences of their immersion services to Manila City Jail-Female Dormitory. The descriptions shared by the respondents were analyzed thematically.

It is ensured that information collected is bound with ethical considerations. Permission to conduct post-evaluative assessment of the program was sought from the Manila City Jail-Female Dormitory officials. In addition, respondents of this study were not forced or complied to join by the Jail officers. An informed consent was also given to PDLs to ensure confidentiality of their answers to the program. Likewise, teacher volunteers' reflexivity papers were secured for privacy.

\section{Results}

Responses of 10 PDLs in the enhancing the reading skills program of Project HOPE derived from the post-evaluative program questionnaire.

Table 1: Participants' evaluation to the content of the program

\begin{tabular}{|c|c|c|c|c|c|c|c|}
\hline & 5 & 4 & 3 & 2 & 1 & Mean & $\begin{array}{l}\text { Qualitative } \\
\text { Interpretation }\end{array}$ \\
\hline $\begin{array}{l}\text { A.1. The } \\
\text { program is } \\
\text { relevant }\end{array}$ & 10 & 0 & 0 & 0 & 0 & 5.00 & $\begin{array}{l}\text { Strongly } \\
\text { Agree }\end{array}$ \\
\hline $\begin{array}{l}\text { A.2. The } \\
\text { program } \\
\text { provides } \\
\text { productive } \\
\text { learning }\end{array}$ & 9 & 1 & 0 & 0 & 0 & 4.90 & $\begin{array}{l}\text { Strongly } \\
\text { Agree }\end{array}$ \\
\hline $\begin{array}{l}\text { A.3. The } \\
\text { program } \\
\text { addresses } \\
\text { my } \\
\text { learning } \\
\text { needs }\end{array}$ & 6 & 4 & 0 & 0 & 0 & 4.60 & Agree \\
\hline $\begin{array}{l}\text { A.4. The } \\
\text { program } \\
\text { helps to } \\
\text { expand } \\
\text { my } \\
\text { knowledge } \\
\text { and skills }\end{array}$ & 9 & 1 & 0 & 0 & 0 & 4.90 & $\begin{array}{l}\text { Strongly } \\
\text { Agree }\end{array}$ \\
\hline
\end{tabular}

Based on the post-evaluative questionnaire answered by 10 respondents, participants of the enhancing reading skills program strongly agree on the statements stipulated in the instrument. All of the participants strongly agree that the program makes sense and relevant with a mean of 5.00. Majority of the participants gave a mean score of 4.90 in terms of 
the program contribution to their learning productivity and in expanding their knowledge; whereas a 4.60 mean score was computed in terms of the program relationship to their needs.

Table 2: Participants' feedback to the performance of the teacher volunteers

\begin{tabular}{|l|l|l|l|l|l|l|l|}
\hline & 5 & 4 & 3 & 2 & 1 & Mean & $\begin{array}{l}\text { Qualitative } \\
\text { Interpretation }\end{array}$ \\
\hline $\begin{array}{l}\text { B.1. The } \\
\text { instructor is } \\
\text { knowledgeable } \\
\text { to the topic } \\
\text { he/she is } \\
\text { discussing }\end{array}$ & 10 & 0 & 0 & 0 & 0 & 5.00 & $\begin{array}{l}\text { Strongly } \\
\text { Agree }\end{array}$ \\
\hline $\begin{array}{l}\text { B.2. The } \\
\text { instructor is } \\
\text { well-equipped } \\
\text { in providing } \\
\text { knowledge } \\
\text { and/or skills } \\
\text { training }\end{array}$ & 10 & 0 & 0 & 0 & 0 & 5.00 & $\begin{array}{l}\text { Strongly } \\
\text { Agree }\end{array}$ \\
\hline $\begin{array}{l}\text { B.3. The } \\
\text { instructor } \\
\text { encourages } \\
\text { participants to } \\
\text { participate } \\
\text { actively in the } \\
\text { learning } \\
\text { session }\end{array}$ & 9 & 1 & 0 & 0 & 0 & 4.90 & $\begin{array}{l}\text { Strongly } \\
\text { Agree }\end{array}$ \\
\hline
\end{tabular}

Meanwhile, Table 2 revealed that teacher volunteers are subject matter expert and have shown good performance in teaching enhancing reading skills. The first two assessment criteria, as shown in figure 3, got a mean score of 5.00 . Likewise, majority of the participants strongly agree to the notion of teachers' way of encouraging the learners to participate actively in the program discussion and activities having a mean score of 4.90 .

It was revealed that the general response of the participants. Majority of the respondents gave a qualitative feedback of strongly agree. They emphasized that the program has clear set goals and it started and ended on time with a mean score of 4.90 . It was also reflected in the post-evaluative assessment of the participants that the program caught their interests, practically, because of the results of the needs assessment conducted by [19] where literacy is among the top five programs that they needed to have. They also pointed out that the flow of the program was well-organized $(\overline{\mathrm{x}}=4.80)$, and a mean score of 4.60 for their assessment in terms of the program venue.

Over-all, the program got a composite mean of 4.86 which reflects a strongly agree qualitative point interpretation. Results revealed that the program have provided impact to participants' literacy needs as expressed in their post-evaluative comments: (1) they have learned a lot and new ways of learning reading; (2) they are thankful because their learnings will be useful once they are free from jail; (3) they wish to have more of literacy programs for individual growth; and (4) they are grateful for the learnings extended by the university.

Actual teacher experiences that transpired in the immersion teaching:

Theme 1: Volunteer Teachers unearthed the relevance and significance of Project HOPE

Data revealed that project HOPE holds significance as educators share time and skills needed by the inmates to advance their growth inside the facility. Educators reflect on the possibility of employment outside jail. One of the volunteers in his reflexivity paper wrote, "our inmates here in Manila are not just literally confined, but a lot of them are also confined by a lack of necessary literacy skills, which include reading, writing, and comprehension. These skills are important for securing employment when they are released, in as much as it is also essential in their remaining days of stay inside, both for continuous academic and psychological development."

The relationship between education and recidivism and concluded that inmates need and yearn educational opportunities that teach not only the fundamentals, but also skills that will foster transition back into society [27]. With this, educators have the dynamic communal role in creating an environment where even inmates can learn and envision a productive life after jail through constructive enhancement of their literacy skills.

Table 3: Over-all response of the participants' to the program goals

\begin{tabular}{|l|l|l|l|l|l|l|l|}
\hline & 5 & 4 & 3 & 2 & 1 & Mean & $\begin{array}{l}\text { Qualitative } \\
\text { Interpretation }\end{array}$ \\
\hline $\begin{array}{l}\text { C.1. The } \\
\text { program has } \\
\text { clear } \\
\text { objectives }\end{array}$ & 9 & 1 & 0 & 0 & 0 & 4.90 & $\begin{array}{l}\text { Strongly } \\
\text { Agree }\end{array}$ \\
\hline $\begin{array}{l}\text { C.2. The } \\
\text { program } \\
\text { catches my } \\
\text { learning } \\
\text { interests }\end{array}$ & 8 & 2 & 0 & 0 & 0 & 4.80 & $\begin{array}{l}\text { Strongly } \\
\text { Agree }\end{array}$ \\
\hline $\begin{array}{l}\text { C.3. The } \\
\text { program is } \\
\text { well-organized } \\
\text { and prepared }\end{array}$ & 8 & 2 & 0 & 0 & 0 & 4.80 & $\begin{array}{l}\text { Strongly } \\
\text { Agree }\end{array}$ \\
\hline $\begin{array}{l}\text { C.4. The } \\
\text { venue of the } \\
\text { program } \\
\text { conducted in a } \\
\text { conducive } \\
\text { learning } \\
\text { environment }\end{array}$ & 6 & 4 & 0 & 0 & 0 & 4.60 & $\begin{array}{l}\text { Strongly } \\
\text { Agree }\end{array}$ \\
\hline $\begin{array}{l}\text { C.5. The } \\
\text { program } \\
\text { started and } \\
\text { ended on time }\end{array}$ & 9 & 1 & 0 & 0 & 0 & 4.90 & $\begin{array}{l}\text { Strongly } \\
\text { Agree }\end{array}$ \\
\hline
\end{tabular}


Theme 2: Emphasis on Participant gains and learnings

Socratic Method and Question Circle paved way for collaboration among inmates. Through group activities, inmates were able to generate understanding of the topic and in turn, go beyond the content by creating questions of their own about the real world. As expressed by the volunteer teacher, "I noticed that the learners are not much into the terminologies, but signs of understanding the concepts discussed were seen, such as their ability to articulate it using their own words, as well as their ability to use such types of questions."

In addition, the volunteer teacher suggested that inmates advanced the cognitive level as they cultivate their affective domain through various activities that touched their ability to feel and have self-perspective. She penned, "what I learned from them the most was their courage - to stay in a place that most of them may not belong, patience -to patiently wait for their loved ones for a visit, endurance - to be physically and mentally healthy to survive and to stay sane in a fourwall place, and determination - to never give up every single minute and to stay positive of a chance of getting out of there."

Theme 3: The inmates' attitudes in participating in the program are positive and active

The inmates posit not just eagerness to participate but also to articulate the concepts and ideas discoursed through various activities they participated in. Furthermore, one teacher volunteer revealed that inmates were attentive, respectful and active in participating in the discussion. The volunteer teacher shared, "...they (inmates) also stood out in the written activity. In the activity, they were grouped, and each group collaborated and answered it with all honesty applying of what they learned from the lecture/demo. The highest score that one group got was 27 out of 30 points. At that time, I could not believe I was in BJMP. They proved me wrong again of my initial perception of them." Additionally, one of the volunteer teachers emphasized that, "I noticed that the learners are not much into the terminologies, but signs of understanding the concepts discussed were seen, such as their ability to articulate it using their own words, as well as their ability to use such types of questions."

Following the Bloom's Taxonomy, the inmates as learners advanced the knowledge level as they begin to share the understanding of concepts and articulate them in their own point of view by asking relevant questions to themselves or towards another inmate.

\section{Discussion and Conclusion}

Many social science researchers pointed out the necessity to improve reading instruction methods among incarcerated offenders, as part of any crime prevention policy [27]. Yet, very little research has been devoted to the study of effective reading and writing techniques in prisons [7]. This study is aimed at the creation of more researches and andragogic pursuits that could further improve literacy in prisons for the purpose of enlightenment that employment and further learning is possible even inside the cells.

In a nutshell, in order to decrease recidivism or reoffending, it is imperative for inmates to become productive and causative individuals even inside the cells. Providing PDLs with opportunity, improvement, and rehabilitation is a law-based responsibility, but offering them projects such as project HOPE is a social responsibility [13]. To foster this rehabilitation and to reduce recidivism, continued correctional education and reentry support programs need to expand and develop.

The enhancement reading skills program is the institute's response to the needs of the PDLs based from the needs assessment study conducted by [19]. Considering the educational attainment profile of the PDLs, it also represents the Philippine education system where multitude of problems exists such as reading literacy. In fact, [8] explained that the ability to read and to write is considered as a priority in the Philippines; thus, there is a need to promote literacy by the government, organizations, or even private institutions.

The FEU-IE's community development program initiative assessed vocabulary knowledge of the PDL participants. [5] defined it as "more than knowledge of the basic meanings of words" (p.18). While [6] revealed in their study that having suitable texts and light literature with great enjoyment can result in substantial vocabulary acquisition. As such, having activities like writing a log about what PDLs are reading would facilitate structure of their thoughts for discussion time [12]. In fact, this notion was also emphasized by [14] wherein the purpose of reading is to enable one's individual to comprehend. This suggests, therefore, that having literacy programs like enhancing reading skills will serve as avenue for comprehension of vocabulary texts towards developing and enhancing one's understanding, for instance, in contextualizing meanings or passages [5].

Thus, enhancing reading skills program catered the needs of PDLs with its aim of inculcating the importance of learning how to read and to comprehend. The purpose also of this program is geared towards providing assistance in developing PDLs' comprehension skills and improving their critical thinking skills through the process of reading skills enhancement.

\section{Acknowledgement}

We would like to extend our gratitude to Dr. Arnel Bravo, Dr. Luzelle Anne Ormita, and Dr. 
Harold John Culala for trusting us to accomplish this paper.

\section{References}

[1] Alibali, M. (2006). Does visual scaffolding facilitate students' mathematics learning? Evidence from early algebra. Retrieved from http://ies.ed.gov/funding /grantsearch/ details.asp?ID=54

[2] Aldaba, F. (2009). Poverty in the Philippines: Causes, constraints, and opportunities. Manila: Asian Development Bank. Retrieved from https://www.adb.org/sites/ default/files/ publication/27529/poverty-philippines-causesconstraints-opportunities.pdf

[3] Baker, J., \& DIGNITY. (2015). Conditions for women in detention in the Philippines: Needs, vulnerabilities, and good practices. Retrieved from https://dignityinstitute.org/ media /2066109/pubserieswid11.pdf

[4] Bloom, B., Owen, B., \& Covington, S. (2004). Women offenders and the gendered effects of public policy. Review of Policy Research, 21(1), 31-48. https://doi.org/10.1111/j.1541-1338.2004.00056.x

[5] Burt, M., Peyton, J. K., \& Adams, R. (2003). Reading and adult english language learners: A review of the research. National Center for ESL Literacy Education (NCLE).

[6] Cho, K. S., \& Krashen, S. D. (1994). Acquisition of vocabulary from the Sweet Valley Kids series: Adult ESL acquisition. Journal of Reading, 37(8), 662-667.

[7] Coulter, G. (2004). Using one-to-one tutoring and proven reading strategies to improve reading performance with adjudicated youth. Journal of Correctional Education, 55(4), 321-333.

[8] Cristobal, L. (2015). Literacy in the Philippines: The stories behind the numbers. Retrieved from https://www.literacyworldwide.org/blog/literacydaily/2015/08/06/literacy-in-the-philippines-the-storiesbehind-the-numbers

[9] Far Eastern University. (n.d.). Institute of education. Retrieved from https://www.feu.edu.ph/manila/index.php/ academics/institute-of-education/.

[10] Gee, J. (2006). Education in Rural County Jails: Need Versus Opportunity. Journal of Correctional Education, 57(4), 312-325. Retrieved August 19, 2019, from www.jstor.org/stable/23282805.

[11] Gee, J. C. (2015). Here and back again: Community reentry from a rural county jail as a learning experience. State College, PA: Pennsylvania State University.

[12] Greenberg, D., Rodrigo, V., Berry, A., Brinck, T., \& Joseph, H. (2006). Implementation of an extensive reading program with adult learners. Adult Basic Education, 16(2), 81.
[13] King, D. K. (2016). Multiple jeopardy, multiple consciousness: The context of a Black feminist ideology. In Race, gender and class (pp. 36-57). Routledge.

[14] MacArthur, C. A., Konold, T. R., Glutting, J. J., \& Alamprese, J. A. (2010). Reading component skills of learners in adult basic education. Journal of Learning Disabilities, 43(2), 108-121. https://doi.org/10.1177/ 0022219409359342

[15] Miller-Warke, J. (2000). Prisoners as women: Questioning the role and place of imprisonment. In Women in corrections: Staff and clients conference convened by the Australian Institute of Criminology in Conjunction with the Department for Correctional Services, Adelaide.

[16] Moeller, M., Day, S. L., \& Rivera, B. D. (2004). How is education perceived on the inside?: A preliminary study of adult males in a correctional setting. Journal of Correctional Education, 40-59.

[17] Nylan, M. (2008). Differences in motivation for prison education between prison offenders and state jail inmates in a state jail transfer facility. Commerce, TX: Texas A\&M University-Commerce.

[18] Ocampo, D.J. \& Hermosa, N. (1997). EDR 210 module: Trends in reading instruction. U.P. Open University, Diliman, Quezon City: Office of Academic Support and Instructional Services.

[19] Ormita, L.A., Grasparil, J.A., \& Alvarez, A., Jr. (2018). Exploring the needs and challenges of detainees: A basis for sustainable FEU Project HOPE. Paper presented at the 4th ASIAENGAGE Regional Conference, Chiang Mai, Thailand.

[20] Philippine Drug Enforcement Agency (2015). 2015 Annual report. Retrieved from http://pdea.gov.ph/images/ AnnualReport/2015AR/AR2015page1to37.pdf

[21] Ruddell, R., \& Mays, G. L. (2006). Expand or expire: Jails in rural America. Corrections Compendium, 31(6), $1-5$.

[22] Samenow, S. E. (1991). Correcting errors of thinking in the socialization of offenders. Journal of Correctional Education, $\quad 42(2), \quad 56-58$.

[23] Shaw, D. M., \& Berg, M. A., M.A. (2009). Jail participants actively study words. Journal of Correctional Education, $\quad 60(2)$,

100-119.

[24] Solomon, A. L., Osborne, J. W., Winterfield, L., Elderbroom, B., Burke, P., Stroker, R. P., \& Burrell, W. D. (2008). Putting public safety first: 13 parole supervision strategies to enhance reentry outcomes. Urban Institute, Washington,

DC.

[25] Steurer, S. J., Smith, L., \& Tracy, A. (2001). OCE/CEA three state recidivism study. Lanham, MD: Correctional Education Association. 
[26] Stinchcomb, J. B., \& McCampbell, S. W. (2008). Jail leaders speak: Current and future challenges to jail operations and administration. Naples, FL: Center for Innovative Public Policies.

[27] Vacca, J. S. (2004). Educated prisoners are less likely to return to prison. Journal of Correctional Education, 55(4), 297-305.

[28] Wodahl, E. J. (2006). The challenges of prisoner reentry from a rural perspective. Western Criminology Review, 7(2), 32-47. 